\title{
Indonesian Migrant Workers in Taiwan: The State Dilemma and People's Realities
}

\author{
Ali Maksum ${ }^{1}$, Ching-lung Tsay ${ }^{2}$, Ali Muhammad ${ }^{3}$ \\ ${ }^{1}$ Department of International Relations, Universitas Muhammadiyah Yogyakarta, Indonesia \\ (email: ali.maksum@fisipol.umy.ac.id) \\ ${ }^{2}$ Department of Diplomacy and International Relations, Tamkang University, Taiwan \\ (email: ctsay200@yahoo.com) \\ ${ }^{3}$ Department of International Relations (Masters Program), Universitas Muhammadiyah Yogyakarta, Indonesia \\ (email: ali.fisipol@gmail.com)
}

\begin{abstract}
The role of migrant workers is frequently marginalized amid industrial development, labor shortages, and the domination of state to state arrangements. In fact, the position of migrant workers should be considered as a primary factor in bilateral relations and trade agreements, notably between Indonesia and Taiwan. The reason is that the influx of migrant workers has undoubtedly given many benefits to both Indonesia and Taiwan governments. The Indonesian government considered that in the midst of insufficient job opportunities, migrant workers working in Taiwan indirectly lowered the unemployment rate. In addition, Indonesia acknowledged the high contribution of migrant workers by remittances to national income. At the same time, Taiwan recognized the importance of Indonesian migrant workers in the national economy, as well as strengthening Taiwan's second-track diplomacy with Indonesia vis-à-vis China. This article argues the dynamics of Indonesian migrant workers in Taiwan, influenced by two factors: (1) the state dilemma and (2) people's realities, affecting the international relations between Indonesia and Taiwan. Therefore, this paper aims to explore possible answers by discussing the state dilemma and peoples' realities from the perspective of Indonesian workers in Taiwan. This study represents qualitative research supplemented by data obtained from interviews with Indonesian workers in Taiwan. The authors are also intensively contacted and involved through activities with Indonesian workers and communities.
\end{abstract}

Keywords:

Indonesian migrant workers; Indonesia-Taiwan relations; role of migrant workers; bilateral (economic) cooperation

\section{Introduction}

Like most countries in the world, Indonesia does not have diplomatic relations with Taiwan. Nevertheless, the non-political, especially economic, ties between the two sides have been rather strong. Both countries are important trade partners to each other. While Taiwan is a major source country of foreign direct investment (FDI) to Indonesia, Indonesia is the leading supplier of contract workers to Taiwan. In recent years, human interactions have also been intensified by other types of migration from Indonesia to Taiwan, such as marriage, higher education, and professional employment.

The migration of Indonesian workers abroad is a part of the global migration phenomenon. Mostly, they moved abroad to seek jobs and to improve their lives (Prihatin, 2007). According to the National Agency for Placement and Protection of Indonesian Workers (BNP2TKI, Badan Nasional Penempatan 
dan Perlindungan Tenaga Kerja Indonesia), Malaysia, Taiwan, and Saudi Arabia are among the major host countries of Indonesian workers. When Taiwan opened its labour market to Southeast Asian workers in the early 1990s, the number of Indonesians was far smaller than that of Thais and Filipinos. By the end of 2018, however, the number of Indonesian workers reached 260 thousand, accounting for 40 percent of Taiwan's total contract workers from abroad (near 700 thousand). Three-quarters of them work as caretakers to the aged and disabled, representing a market share of 75 percent. The rest of the Indonesians are employed in manufacturing and fishery industries (BNP2TKI, 2019).

The majority of Indonesian workers in Taiwan have realized their expectations of the migration to Taiwan. Furthermore, they have enjoyed the migration gains either in Taiwan by themselves or/and with their families in Indonesia. As a result of increased length of staying and working in Taiwan, many Indonesian workers have been deeply involved in economic, community, and family activities, as well as in the daily lives of Taiwanese people (Tsay, 2015). There is clearly the cohesion of Indonesian migrant workers with Taiwanese. In the process of migration to Taiwan, Indonesian workers have experienced the change from "being unemployed at home" to "being cohered with Taiwanese."

The close economic and cultural interchanges between Indonesia and Taiwan, as briefed above, reveal the de facto partial Government-to-Government (G-to-G) relations existing between Jakarta and Taipei. This paper attempts to examine the existence of Indonesian migrant workers in Taiwan, the contribution, and its impact on Indonesia-Taiwan relations. This article argues the dynamics of Indonesian migrant workers in Taiwan, influenced by two factors: (1) the state dilemma and (2) people's realities, affecting the international relations between Indonesia and Taiwan. State dilemma refers to the fact that Indonesia and Taiwan have no official diplomatic relations. Instead, people's realities reflect the actual relationship between the two societies, Indonesia and Taiwan. Therefore, this paper aims to explore possible answers by discussing the state dilemma and peoples' realities from the perspective of Indonesian workers in Taiwan. In the subsequent paragraphs, the authors will briefly explore the G-to-G partial relationship, methodology, the main section on the state dilemma, and people's realities, followed by challenges and opportunities analysis, which is obviously imperative for policy makers.

\section{Partial G-to-G Relationship}

Partial G-to-G relationship was closely related to the concept of two states' diplomacy in international relations. The typology of diplomacy is generally divided into two main discourses, namely traditional diplomacy and public diplomacy. Traditional diplomacy involved a very high-level of the state to state diplomacy, using official representativesnotably, ambassadors, consulates, special envoys - and engages in negotiations, with a wide range of issues discussed (Barston, 2019). In addition, there is public diplomacy in order to foster government efforts under traditional diplomacy, while states sometimes faced obstacles and tend to stagnant. Therefore, public diplomacy is offered in order to resolve negotiation deadlock during official dialogues using conventional diplomacy (Cull, 2010). In this context, Indonesia-Taiwan relations faced challenging problems concerning the status of Taiwan vis-à-vis China. The role of people-topeople relations is critically important to boost Taiwan's diplomatic strategy. Indeed, migrant workers and its interpersonal approach theoretically and strategically included as an agent of public diplomacy (Tam, 2019). The role of non-state actors in the state's diplomatic efforts is also known as second tract diplomacy (Mursitama, 2012). While the track 
one diplomacy refers to the state's traditional diplomacy, as above mentioned, it sometimes weakens its potential contribution to the policymaking process and during negotiations (Schiff, 2010).

Some scholars examined public diplomacy and deliberately worked to boost partial G-to-G relations. This was effectively implemented generally by the state, with problematic recognition such as South Korea, North Korea, Armenia, Israel, People's Republic of China, and Taiwan. South Korea is known as a leading country that uses public diplomacy through culture to gain international community awareness of the country vis-à-vis North Korea and vice versa North Korea did (Cathcart \& Denney, 2013; Cho, 2012; Mo \& Hahn, 2005). However, to some extent, public diplomacy faced challenging issues for a country that controversially existed like Israel (Gilboa, 2006; Medzini, 2012). The Taiwanese strategy to use 'soft power and public diplomacy' has greatly been maximized to foster national interest. Moreover, the strategies have also played a pivotal role to counter international and public suspicions (Rawnsley, 2014).

In this context, few authors have examined Indonesia and Taiwan relations related to Indonesian migrant workers. Kabinawa (2013), for instance, argues that amid no official diplomatic relations, both people from three different groups have shared the idea with Taiwan's counterpart in order to strengthen both countries' relations. By emphasising on education cooperation between the government of Taiwan and Aceh province in Indonesia, according to Mashitah (2017), both sides gained benefits. For Aceh, this cooperation increased the number of Aceh people to study abroad, especially to Taiwan and vice versa, Taiwan benefited from its cooperation to promote the country's diplomacy. These two explanatory research was presented without a specific theory of diplomacy or foreign policy explained.
Meanwhile, Loveband (2003) focuses more on how Indonesian migrant workers' deployment and its treatment were received while some extent exploitation still occurred, especially in domestic workers. In contrast to this, Yuniarto (2014), using the migrant entrepreneurs adjustment approach, said that the Indonesian diaspora, including migrant workers, was well treated and hugely benefited from social capital among them to build the business network in Taiwan. Social media is one of the primary strategies to build such a business network and various activities. In addition, why they are close together is because they have a so-called 'moral obligation to the community (Yuniarto, 2015). The three articles were noticeably based on a sociological perspective rather than being analysed by a partial diplomatic approach.

Melchert (2017) prefers to assess social cohesion between Indonesian migrant workers and Indonesian students living in Taiwan from an anthropological approach, in relation to religion and life-style. Since this literature emphasised religious and life-style points of view, the research revealed that differences in family background between students and the workers influenced the level of social cohesion among Indonesian in Taiwan. In the meantime, Faustina (2015) is the only G-to-G relationship that focuses on Indonesia and Taiwan cooperation related to migrant workers. Specifically, this thesis found that both countries have a different objective and seek to defend 'national interest' on both sides. As a consequence, this was led to a high number of Indonesian migrant workers runaway from the employers. In contrast to Faustina (2015), many Indonesian workers were satisfied working in Taiwan, especially the care workers sector, due to wages and work environment factors (Setyaningsih, 2011). In addition, based on her research, which was conducted through a survey with a snowballing approach, the characteristic of the caretaking job also 
influenced job satisfaction among Indonesian care workers.

In essence, previous literature has attempted to examine Indonesian migrant workers in Taiwan from various perspectives. However, no specific literature emphasised the significance of the partial G-to-G relationship approach to understanding Indonesia and Taiwan relations. The only literature that focuses on the G-to-G relationship was prepared by Fauzstina (2015), but she does not clearly discuss the partial relationship between Taiwan and Indonesia and only focuses on one issue: the education sector. Therefore, Indonesia and Taiwan realised partial G-to-G relationships through various channels, such as peoples, organizations, companies, etc., obviously significant to sustaining mutual, beneficial relationship. Further, this kind of partial G-to-G ties, using non-state actors, is strategically brilliant amid the state's sovereignty constraints in countries that have limited international recognition, such as Taiwan.

\section{Methods}

This is qualitative-based research is also enriched by non-structured interviews with selected people. In order to get access to the respondents, the researchers have arranged strategies to conduct the interview, whether through direct interaction, such as personal contact, or correspondence by e-mail and also through social media. This qualitative research is run concurrently starting from data collection, data analysis, and data interpretation. This is because the data of qualitative research is subjective, interpretative, descriptive, comprehensive, and the number is massive. The findings are presented mainly in quotation forms (AN Bakar, 2009) or preliminary description of the data, including statistical data obtained from official resources (Ruenwai, 2006). In addition, data presentations are also in form of key quotations, tables, graphs, etc. Moreover, direct quotes, statements/stories, or quotations from interviews, FGD, fieldwork notes, or primary data are the main method used in this research (Anderson, 2010). However, basically, the data presentation from data analysis in qualitative research is flexible (Mohajan, 2018). Since this is qualitative research, this research used purposive sampling. Accordingly, purposive sampling is important to obtain quality data, yet the researcher must be seriously aware and ensure the reliability and competence of the selected informants (Etikan, Musa, \& Alkassim, 2016). The people who have been interviewed for this study are mostly Indonesian migrant workers. During four months of research fieldwork in Taiwan in 2018, the authors have interviewed six Indonesian migrant workers that reside across Taiwan, such as in Taipei, New Taipei City, Changhua, and Kaohsiung. Moreover, we also surprisingly could obtain data from Indonesian expatriates, Indonesian economic-trade representatives, local Taiwanese as well as Indonesian females who married with Taiwanese in Taiwan. At the end of the next section, we provided analysis for obstacles and opportunities of Indonesian migrant workers in Taiwan.

\section{Results and Discussion}

\section{The State Dilemma: One China Policy versus Economic Interests}

Indonesia-Taiwan relations are unique since both do not maintain official bilateral relations vis-à-vis China. Nevertheless, both countries have enjoyed productive cooperation in various aspects and are not confined only to politics. The development of Indonesia-Taiwan relations is obviously different compared to Indonesia-China relations. Indonesia-China relations have often been characterized as a roller-coaster ride in line with the political situation from time to time. During Sukarno's administration, Indonesia-China relations were clearly in harmony since both countries were 
communist supporters. In contrast, during the Suharto era, Jakarta suspended relations with Beijing following the strong allegation of Chinese involvement in the Indonesian coup of 1965 (Zhou, 2014). The relationship was restored in 1990, although this was domestically controversial. The Sino-Indonesia normalization of relations after the Cold War was a strong indication that Indonesia's foreign policy posture was ready to deal with major powers. Nevertheless, the re-establishment of relations was faced with challenges, especially pertaining to the threat of Chinese involvement in Indonesian domestic affairs (Sukma, 1994, 1995).

This was a reality if the discussion on Indonesia-Taiwan relations should include China's position as an important actor in international relations. The issue of One-China Policy always arises amid Indonesia-Taiwan flourishing cooperation in various sectors. Although Indonesia and Taiwan do not have official political relations, the relationship between Jakarta and Taipei is fruitful. In fact, since the late 1960s, both countries' relations, specifically their economic ties, have resulted in significant achievements. Indonesia's good relations with the island are primarily triggered by Taiwan's rapid economic development since the late 1960s. At that time, Indonesia also perceived that Taiwan's economy was more advanced as well as more willing to offer technology transfers to Indonesia compared to China. As a result, since the 1980s, Taiwan has become one of the major Indonesian foreign direct investments (FDI), especially in the manufacturing sector (Atje \& Gaduh, 1999).

Based on the information above, the discourse on Indonesia-Taiwan relations can fundamentally be traced through two narratives, namely government-to-government contact and non-state relations. Both countries understand that under international anarchy, international relations are very risky (Waltz, 1979). Nevertheless, globalisation has transformed international politics and the role of non-state actors has also increased, which also influenced the two countries' behaviour (Ataman, 2003; Saner \& Yiu, 2001). Therefore, the two countries attempt to resolve the political barriers amid the One China Policy through Second Track diplomacy, which is the solution (Mursitama, 2012). To Indonesia and Taiwan, the establishment of a formal relationship is inevitable, to move beyond the "state centric" one as proposed by mainstream international relations theories. Even though formal political relations are difficult, economic ties are the rational decision to boost relations. As a result, the two parties have established a so-called "trade office" in their respective capital cities to facilitate economic cooperation, which has been widened in various sectors.

Indonesia-Taiwan relations are obviously lacking political influence vis-à-vis China, which has significantly penetrated Southeast Asian politics and economy. As a result, Taiwan finds it difficult to achieve its interest in the region, including in Indonesia. In this context, what Taiwan has done is fulfil a realisation of what is called "global economy", which allows for non-state actors to play roles in international politics. In fact, Taiwan has used second track diplomacy, the private sector, as a basis for Indonesia-Taiwan relations. Under this scheme, Taiwan has successfully become a member of Asia Pacific Economic Cooperation (APEC) and stood equally with China and Indonesia (Atje \& Gaduh, 1999).

Specifically, under this complex situation, Taiwan's efforts to foster and realise G-to-G partial relationship was carried out through huge investment in Indonesia. Taiwan's investment in Indonesia was articulated in some agreements and the operation of Taiwan's companies. Taiwan has operated more than 2,000 enterprises across the countries with numerous business projects. Among Taiwan's companies operating in Indonesia were KENDA Rubbers, Din Tai Fung Restaurant, 
Bao Cheng footwear enterprise, ASUS, Acer Inc., Maxxis, Fengtay, Les Enphants, Tainan Enterprises Co. Ltd., CTBC Bank Indonesia, Makalot Industrial Co. Ltd., TECO, Nan Ya Plastics Corporation, Uni President Corps., E United Group, TATUNG, and many more. The strong relationship on trade between the two countries has significantly affected the economic transaction. From 2014-2016 for instance, Indonesia's export to Taiwan tended to decline markedly. In 2014, export from Indonesia to Taiwan was about USD 7.3 billion, and the following years, 2015 and 2016, the number was decreased to USD 5.9 billion and USD 4.3 billion. Conversely, Indonesia's import from Taiwan was negative and dropped significantly from USD 3 billion in 2014 to USD 2.7 billion in 2016. Consequently, the trade transaction also fell from USD 11.2 billion in 2014 to USD 7 billion in 2016. In this context, Indonesia's government gained more profits from the trade transaction, yet, generally, has also decreased from USD 3.5 billion in 2014 to USD 1.5 billion in 2016 (TETO Jakarta, 2017).

In other sectors of society and culture, Taiwan's investment in Indonesia has also increased from time to time. This was indicated by the number of Indonesian students in Taiwan, especially at the higher education levels from non-degree to Ph.D. degrees. The latest data show that Indonesian students in Taiwan reached 6,811, consisting of Ph.D., masters, and bachelors approximately 4,000 students, and the remaining were exchange students (317) and Mandarin language course students $(1,626)$ (TETO Jakarta, 2017). This is an indication that although Taiwan invested mostly in industrial sectors, social, cultural, and education sectors were not neglected. Although, statistically, both countries' trade transaction was declined, the Taiwan government is still committed to boosting more investment to Indonesia. This was expressed by Taiwan's government and businesspersons following some economic and political changes made by Indonesia's Joko
Widodo. The commitment of the Taiwanese government and businesspersons was generally the implementation of Taiwanese "southward looking policy" (Sundaryani \& Wirayani, 2016). Thus, the influx of Indonesian migrant workers in Taiwan and the rise of Taiwanese investment in Indonesia indicates that both countries have enjoyed good relations. Although both countries have a political barrier, people-topeople contact between the two countries has been relatively smooth in various aspects, including trade, labour, small and medium enterprises, education, and culture due to the implementation of the partial G-to-G relationship.

\section{People's Realities: "Unemployed at Home" to "Cohered with Taiwanese"}

The high number of Taiwan's investment in Indonesia, the existence of migrant workers, and the Indonesia-Taiwan relations are the three aspects that correlate with each other. Taiwan's investment in Indonesia has created more job opportunities for Indonesian local workers. Meanwhile, Taiwan's economic advancement since the 1980s has offered job vacancies for Indonesians in various manufacturing industries, services, and domestic sectors in Taiwan. The role of Indonesian labour, whether in Indonesia or Taiwan, has affected Taiwan's economic performance. In this context, the creation of jobs following the influx of Taiwanese investment in Indonesia has significantly contributed to the Indonesian economy. Yet, the kindness of Taiwan's government on migrant workers, including those from Indonesia, is strong evidence that Indonesian migrant workers in Taiwan have been considered as an important actor in Indonesia-Taiwan economic relations. Therefore, this became a concern for Taiwan's government to take responsibility for and care of Indonesian migrant workers. This policy was basically to maintain good relations with their home countries (Rickards \& Jane, 2017). As a 
result, most Indonesian migrant workers in Taiwan are well treated by Taiwanese families. The comfort of Indonesian migrant workers in Taiwan was important since many Indonesian were employed in the domestic sectors, which are recognised as risky jobs. Nearly $79 \%$ or 170,000 of total caregivers in Taiwan were Indonesian females (J. Chou \& Kuo, 2016).

The development of Indonesian migrant workersin Taiwan and the relationship with both countries' economic ties should be understood comprehensively. Many Indonesian workers in Taiwan have experienced work as well as life differently compared to other Indonesians. The differences in environment, foods, lifestyle, and religious experiences in Taiwan have influenced Indonesian migrant workers' livelihood. Indirectly, this situation has shaped "a new life" among Indonesian migrant workers in Taiwan and has made an impact on Indonesia-Taiwan relations. The engagement of Indonesians in the social and economic activities in Taiwan has significantly contributed to the form of a new people-to-people relationship between the two countries. This is because the participation of people in diplomatic activities is important since the nature of diplomacy is generally dominated by the state (Keliat, 2003; Payne, 2009). In this context, the strong relationship between Taiwanese and Indonesians in Taiwan should be considered the main point to make Indonesia-Taiwan ties stronger. Therefore, economic cooperation is expected to flourish and enlarge in line with strong engagement among their peoples.

At the bottom level, the people-to-people relationship is generally already established since Indonesia and Taiwan engage in various social and economic activities. The engagement of Indonesians in Taiwan, especially migrant workers, can be observed in two issues, namely marriage and economic interactions. Although there have been some obstacles, such as religion and cultural issues, the interaction and cohesion between the two societies is fruitful.
For Indonesian who have stayed in Taiwan for a while, all the problems are easy to resolve and many of them can adjust to local cultures, including the language barrier. The increasing level of interaction between Indonesians and Taiwanese is interesting since Taiwan has faced a serious problem with fertility decline and low birth rate specifically after the 2000s. As a result, the state is under threat of problems, such as social-culture, economic, health-care industry, as well as education issues (Chen, 2012; W.-I. Lin \& Yang, 2009; Y.-W. Lin, Yen, Yen, \& Chu, 2007). Indirectly, the existence and active engagement of Indonesian workers has helped Taiwan's government tackle the population imbalance.

During the observation in Taiwan, there have been some stories that could be highlighted in this section. Many Indonesian workers have been treated well and some of them have special relationships with the locals. The main reason why Indonesian workers are married to the locals is to improve life quality and open more economic opportunities, especially to open stores. This research depicts that most Indonesians in Taiwan who have run business activities can be divided into four groups: 1) Indonesian of Chinese descent, 2) Indonesian-Taiwan business collaboration, 3) former Indonesian migrant workers, and 4) Taiwan graduates. Some of them were the members of the Indonesian Businessman Association in Taiwan (APIT, Asosiasi Pengusaha Indonesia Taiwan) (Yuniarto, 2014). Until 2014, about 300 Indonesian were doing business in Taiwan with various types of enterprises, such as remittance services, shipping, restaurants, and outlets specialised for Indonesian goods (Yuniarto, 2015).

An Indonesian worker based in Changhua City and is employed in a stainless-steel factory mentioned that some Indonesians are married to the locals. Most of them who are married to Taiwanese have improved their job opportunities and reached good positions 
in the company. Usually, Indonesian women who are married to Taiwanese men follow through with the conversion of her religion to his. Yet, if the woman is Taiwanese and the man is Indonesian, the Taiwanese woman will follow the Indonesian and convert to the man's religion. In fact, once an Indonesian is married to a Taiwanese, they commonly will open a business outlet and run entrepreneurial activities. As the respondent mentioned, the marriage between Indonesians and Taiwanese has indirectly helped the communication gap between Indonesian workers and Taiwanese employers. This is because the supervisor appointed by the companies is an Indonesian who is married to a Taiwanese, holds Taiwan citizenship, and can speak fluently in Bahasa Indonesia with Indonesian migrant workers (Interview, 3 May 2018).

Meanwhile, during an interview with Indonesian migrant workers who live in Kaohsiung City, they have other stories about the Indonesians' experience in the city. He has been employed in a car seat cover manufacturing industry since 2014. His journey and process to work in Taiwan were smoothly managed due to his relatives. His brother in law was previously in Taiwan and worked in the same factory that assisted him to register in the company. According to him, he enjoys living in Taiwan, especially in Kaohsiung City. He told me, "I like staying in this city, and, likely, I do not want to return to my village in Indonesia. I do not know what I can do in Indonesia if I return." He added, many Indonesian are married to Taiwanese. Usually, the couple is between Indonesian females and Taiwanese male. The existence of the so-called "Toko Indo" (Indonesian stores) in Taiwan was initiated by Indonesian-Taiwan couples. In his surrounding areas, some of Indonesia's females who are married to Taiwanese came from Cilacap Regency, in Central Java. The "Toko Indo" has obviously attracted and benefitted many Indonesian workers in that city who have highly demanded halal food and beverages (Interview, 7 May 2018).

Some of the Taiwanese are also married to Indonesian women due to religious reasons. Mr. Ahmad (anonymous) is a Taiwanese who has converted to Islam and married an Indonesian girl originally from Pekalongan, a Regency in Central Java. He told me he was born in Jakarta and decided to return to Taiwan when he was 18 years old. He had elementary and high school educations in Indonesia before he finally converted to Islam. He lives in Taipei City not far from Taipei Grand Mosque and usually goes to the mosque almost every day. He then became a key person who could assist many Indonesians in Taipei, especially to resolve problems such as housing issues. One day, an entourage from one of the biggest Islamic organisations in Indonesia sought to establish an office branch in Taipei, yet it was faced with difficulties regarding housing for office centres. Mr. Ahmad helped to contact a landlord and finally gained a suitable house for rent for about two years. He felt happy to assist Indonesian Muslims. He added that he did not have children yet and wanted to go for an insemination operation soon (Interview, 5 May 2018).

The author has also witnessed a close relationship in the context of "people-topeople" relations between Indonesia and Taiwan. In an interview with one of the Indonesian workers, he told an interesting story since he has been living in Taiwan for more than four years. He has used the opportunity in Taiwan to boost his quality of life, not only in terms of economy but also in educational and even social experiences. Amid a very tight schedule, he is a part-time student in a local university, majoring in a subject that was curious about agriculture. He could use extra time after working hours, mostly at night, to study agriculture and it opened his mind to that topic. He is also eager to practice his knowledge once he has completed his contract and returns 
to Indonesia. In addition, he is a musician, a vocalist to one of the local bands in Taipei called "The Mandalas" and held some concerts around Taipei. Interestingly, the members of the band are a mix of both, from Indonesia and Taiwan. There are two Taiwanese in the band: a man, who is the bassist and also serves in the Republic of China Navy, and a woman, a keyboardist who is studying at National Taiwan University. According to him, all songs played by "The Mandalas" are in Bahasa Indonesia. The main reason why both Taiwanese join the band is that they want to gain a new experience playing music with an Indonesian rock band, but their performance is a local taste with Batik clothes and this contradicts with the common "rock music-style." He also admitted that the appreciation of Taiwanese to their band is apparently high and made him so impressed. One of Taiwan's museums asked him to give his performance shoes to be displayed together with other museum's collections (Interview, 1 May 2018).

The warm people-to-people ties between Indonesia and Taiwan, especially among migrant workers in Taiwan, was enhanced by the hospitality of the employers. Many Indonesian workers have been continuously practicing their religion, especially the Muslim workers. Through religious relations among migrant workers, they have also built business networks as well as a community (Yuniarto, 2015). The comfort of the Indonesian Muslim community is at least represented by the existence of the branches of the two largest Indonesian Islamic organisations, namely Muhammadiyah and Nahdlatul Ulama (NU). Both organisations have collaborated in some agendas and indirectly serve as a "gathering place" for many Indonesian workers in Taiwan. Most of the agendas that have used public facilities in Taiwan have been permitted and facilitated by local governments (Interview, 1 May 2018). This kind of comfortable situation also occurred inside the working environment.
As mentioned by an Indonesian caregiver in Taipei, he can perform his religious practices freely. This is because "my boss totally understands that religion is important, and I can be free to pray as long as I can adjust and ensure my praying schedule did not clash with working activities," and that is why he was allowed to practice his religion (Interview, 17 May 2018).

At this point, we can arrive at the conclusion for this section that the role of Indonesian migrant workers in Taiwan is important in order to strengthen IndonesiaTaiwan partial G-to-G relationship. The hospitality towards Indonesian workers obtained in Taiwan demonstrated the good "people-to-people" relations at the grass-root level. This obviously matches with Taiwan's New People-Centred Southbound Policy, which strives to boost the relationship between Indonesian and Taiwanese. In this context, based on daily life and experiences, Indonesian migrant workers in Taiwan have played a significant role in enhancing bilateral relations. Consequently, the sustainability of economic cooperation between the two countries will continuously be achieved. Taiwan is perceived positively compared to China, which is seen as a threat amid the influx of Chinese unskilled workers to Indonesia. In contrast, Indonesian workers enjoy working in Taiwan due to being well received and treated fairly. This also reveals a strong indication that a partial G-to-G relationship works vis-à-vis China's and some political barriers.

\section{Challenges and Opportunities}

The existence of Indonesian migrant workers in Taiwan and the initiation of the New People-Centred Southbound Policy has invited many parties to take part in the agendas. This is in line with the concept of G-to-G partial relationship that takes into account multidimensional strategy and actors. However, migrant workers must be paid more 
attention to as a basis for this kind of policy since their contribution was highly appreciated. Therefore, in the next section, I will provide two aspects: obstacles and opportunities concerning the Indonesian migrant workers in Taiwan.

\section{Challenges}

In the context of Indonesian migrant workers in Taiwan, some obstacles have been addressed and resolved. Based on field observation, the obstacles could be divided into at least three aspects, namely economic context, social-religious context, and political context. The three components are very important to maximise the role of Indonesian migrant workers to boost Indonesia-Taiwan economic cooperation. The three elements are also critical due to their indirect influence on the nature of people-to-people as a basis for relationship between two countries.

Economic Challenges. In terms of economy, there are some obstacles related to the presence of Indonesian migrant workers and IndonesiaTaiwan relations. The problems arose once the contract was abused by Taiwanese employers. During the observation, some Indonesian workers mentioned that after receiving their first month's wages, they noticed that the salary they received was different than the one negotiated in the signed contract. They said this is because the employers assumed the workers did not understand the Mandarin language, but once the workers clarified, the employers agreed to change their decision. Also, worker agents in Indonesia have a bad attitude by collecting extra money from the workers, although they have been paid by Taiwan's employers as agreed in the contract. However, once the workers clarified with employers, the agents agreed with the decision. This means that there are some serious problems if the government did not make serious and tight supervision, whether for the employers or the local agents in Indonesia. All these issues related to the disruption of workers' income resources would be a serious problem in the future. In addition, the workers must also pay a monthly fee to Taiwan agents, which also made them under pressure. Generally speaking, "the first year in Taiwan is a voluntary job" (Interview, 27 May 2018). Nonetheless, Indonesians still continue to come to Taiwan since the number of jobs in Indonesia is so limited as a result of the high unemployment rate.

Social - Religious Challenges. In the context of social-religious issues, there are some problems. Specifically, among migrant workers from Indonesia, they admitted that they could not perform their religious practices properly during working hours. The majority of Indonesian migrant workers could not perform their Friday Prayer (salāt al-jumu'ah), which is recognised as a compulsory congregational prayer for male Muslims due to the job barrier. At the same time, the company owners also did not allocate prayer space, although in very minimum size for daily prayers. Nevertheless, Indonesian migrant workers could not do anything and missed prayers to reach job and economic demands. "Yes, I could not perform Friday Prayer and even daily prayers. [...] it is very difficult for me. [...] sometimes I did replacement prayer once I arrived at home" (Interview, 7 May 2018). Instead, due to distance problems from the mosque location, ${ }^{1}$ "I just performed 'honorary Friday Prayer' at that time to honour the prayer" (Interview, 27 May 2018). In other situations, many IndonesianTaiwanese couples faced relationship problems due to cultural and religious differences. Some Taiwanese spouses only pretend to convert to Islam, yet they did not perform daily prayers. Meanwhile, Indonesian spouses could not do anything and often asserted that they missed God, empty of God, and miss their previous life in Indonesia, in which they can perform daily

\footnotetext{
1 There are only two mosques located in Taipei, namely Taipei Grand Mosques (Xin sheng South Road) and Taipei Cultural Mosques (Xinhai Road).
} 
prayers and live as a true Muslim (Interview, 24 May 2018). At the same time, there are negative perceptions among the locals toward migrant workers, including from Indonesia. Taiwanese locals are often disturbed by the attitudes of migrant workers due to their disruption in the public space. They often gather in public facilities, drinking, doing karaoke, and making other noisy activities that resulted in public complaints (Koike, 2015). In addition, the number of Indonesian migrant workers involved in criminal activities is relatively high. The latest update, May 2018, depicts that Indonesia ranked as the third-largest country committing criminal activities in about 21 cases, below Thailand (39 cases) and Vietnam (87 cases) (Ministry of Labour, Republic of China (Taiwan), 2018).

Political Challenges. The political obstacles faced in relation to Indonesian migrant workers in Taiwan are relatively the elite's business. This is because, for the grassroots level, notably migrant workers, the political issues between the two countries are far from their minds. Until now, there is no specific problem emerging from the Indonesian migrant workers related to political issues between Taiwan and Indonesia. Instead, awareness came from Indonesian students in Taiwan. They are worried about the status of Taiwan vis-à-vis the People's Republic of China that might become a problem in their future career (Interview H). In contrast to this, many Indonesian migrant workers perceived political issues in an easy manner, even in the eyes of Indonesian illegal workers. Many illegal workers from Indonesia who lost their jobs or escaped from their employers and became illegal still continue with the latest illegal jobs. If their position was detected by authorities, they only transfer to other new jobs and safe places until they could disguise as much as possible. Once they decide to finish and return to Indonesia, they only need to come to the Indonesian trade and economic office in
Taipei to request a document called as "Travel Document in Lieu of a Passport" (SPLP, Surat Perjalanan Laksana Paspor), since their passport and visa were expired (Interview, 27 May 2018).

In the meantime, in the context of diplomatic business, there are no official representatives, especially from the Ministry of Foreign Affairs of the Republic of Indonesia, since the Indonesian government adopted the "One China Policy." The diplomatic mission is run by the Indonesian Economic and Trade Office (KDEI) in Taipei under the Ministry of Trade of the Republic of Indonesia supervision. Inside KDEI, there were some "diplomatic representatives" from the Indonesian government, such as immigration, BNP2TKI, consular, tourism, excluding the Ministry of Foreign Affairs. All the divisions were under the head of KDEI coordination. The head of KDEI conducts his assignments in place of a "consul/ambassador." Once problems related to Indonesian workers in Taiwan emerge, such as escape from employers, contract violation, and other problems, generally, the KDEI, along with other divisions, will coordinate with the Taiwan government. This was also mentioned in objective number four that KDEI is the representation of the Indonesian government interests in Taiwan (KDEI Taipei, 2014). In this context, of course, Indonesian-China relations is the main barrier for Indonesian and Taiwanese to enhance political ties. It means, like other countries, the Indonesian government has taken a moderate diplomatic strategy with Taiwan vis-à-vis China and other primary actors of international relations. Nevertheless, overall, there are no significant problems raised pertaining to economic relations that have been committed by Indonesia and Taiwan since the relationship has been established for many decades.

\section{Opportunities}

There were so many opportunities in Indonesia-Taiwan relations concerning the 
existence and the role of Indonesian migrant workers in Taiwan. Based on the above explanation, this section is divided into three parts: economic opportunities, social-religious opportunities, and political opportunities.

Economic Opportunities. In terms of economic opportunities, this is probably the biggest opportunity in the context of Indonesian migrant workers in Taiwan. The economic relationship between Indonesian and Taiwanese was fruitful. The empirical observation demonstrates that many Indonesian workers in Taiwan spent much more money on their daily activities. Indonesian workers were also known as the over spender people. They did not hesitate to spend a lot of money to buy their needs, such as foods, beverages, clothes, and lifestyle. During my interview with an Indonesian workers said that: "I want to buy chocolates; all the good chocolates were sold out. I know this is because a month before Eid al-Fitr celebration, most of them will return to Indonesia and buy all chocolates for souvenirs. I admit that Indonesian were over-spender people and they did not care about the financial balance" (Interview, 27 May 2018). This means that the Taiwanese economy benefited from the existence of Indonesian workers.

Meanwhile, there have been many "Indonesian shops" called "Toko Indonesia" or "Toko Indo" across Taiwan where many Indonesians reside. To be sure, most of the buyers were Indonesian workers. The shops provide Indonesian products, such as instant noodles, biscuits, soft drinks, cosmetics, and clothes. Furthermore, the shops also employ "Indonesian chef" to provide Indonesian taste foods. The majority owner of the Indonesian shops were Indonesian-Taiwanese couples. Besides that, many Indonesian workers were also attempting to get extra money by selling Indonesian products on a very small scale. They usually leave their product in the Indonesian shops and will share the profits with the owners. The existence of
Indonesian shops in Taiwan also cultivates local business where many Taiwanese also became importers for various Indonesian products. Also, many Taiwanese Muslims are happy to visit Indonesian shops since they provide Halal foods, which are so important. At the same time, Indonesian Muslims, especially migrant workers, also thank these Taiwanese Muslims for providing some critical goods like beef, chicken, and processed meat (like sausage), which require a Halal warranty during the slaughtering process.

For the Taiwan government and businesspersons, this is a big opportunity to strengthen economic ties with Indonesian. Since the last decades, Taiwan has witnessed not only Indonesian migrant workers but also many Indonesian Muslims and from other countries visiting this country. Of course, the demand for Halal foods is high and this should be responded to by Halal food providers opening more stalls and outlets across the country. This is important in order to ensure the demands of Halal foods for Indonesian and Muslims from other countries. For Muslims, Halal food is critical since it is a religious obligation. Further, Halal foods are important, not merely for Muslims but also for nonMuslims, as Halal means "safe, wholesome (toyyiban) and hygienic properties" (Norrakiah A. S. \& Dahlan, 2015). It means the demand for Halal food has significantly increased from time to time. At the same time, for many Indonesian businesspersons, this is also an opportunity to boost investment in the Halal food industries in Taiwan. Nevertheless, this situation should be supported by Halal-friendly policy, especially on investment regulations for small and medium enterprises.

Meanwhile, Taiwan businesspersons also have a big chance of investing in Indonesia. In the manufacturing industries, Taiwan has shown they are the master of hardware providers, especially computer laptops. Asus and Acer are the two Taiwanese most popular 
brands that have dominated Indonesian laptop users since the last decade. According to the latest update, both Acer and Asus have occupied the laptop market in Indonesia, about $40.5 \%$ for Acer and approximately 21.8\% for Asus in the third quarter of 2017 (B. Chou, 2019). This is a strong indication that Taiwanese products, notably laptops, have received good recognition among Indonesian users and the trends will likely sustain in the next years. Therefore, since the trust of the Indonesian people of Taiwan becomes much better and increases from time to time, the Taiwanese investment in Indonesia also has to be enhanced, not only in the manufacturing sector but also in other sectors. Nevertheless, the most important thing is that the investment must yield more job vacancies to Indonesian and also cultivate local industries, especially on technology transfer as the main requirement from the Indonesian government (Indonesian Law No. 25, 2007).

Social-Religious Opportunities. This is also one of the areas in which both countries and people have a harmonious relationship. Through social-religious ties, both societies have a chance to know each other, even though some gaps have been elaborated above. However, the opportunities are still open to both societies to boost relationships, especially between Indonesian migrant workers and Taiwanese. Under the economic relationship, it is likely the most important way to improve the social-religious connection. This is because, under the economic umbrella, both people could share and exchange goods and, of course, economic benefits. Many Indonesians have business relationships, especially those who are married to Taiwanese. Most of them run the business sectors through "Toko Indo" (Yuniarto, 2015). The easier regulation to run business in Taiwan is important so as to give more outlets that sell Indonesian products. Since most Indonesian workers are Muslim, it is important to provide and ensure Halal goods for Indonesian, especially from local products. In this context, the role of Halal quality control institutions is critical.

Amidst the negative perception of some Taiwanese against Indonesian workers (Koike, 2015), many Indonesians also attempt to conduct positive activities. Under KDEI initiation and coordination, many Indonesian have organized Islamic and national activities in every specific moment, such as Holy Ramadan, Eid celebration, Indonesian Independence Day. The involved organisations were PCIM Muhammadiyah, PCINU Nahdlatul Ulama, FORMIT, MTYT, and others. One of the Indonesian workers interviewed in Taipei Main Station revealed that she has been involved in weekly activities under her community called "Persaudaraan Setia Hati Terate (PSHT)", a martial arts organisation from Indonesia. When she was asked whether such kind of activities are prohibited, especially by the local authority, because the activities were conducted in the public facilities, she pointed out that "for them (Taiwanese), this is positive activities. And we have been interviewed, covered, and released in the TV channel by a local journalist" (Interview, 9 July 2018). This is a strong indication that although some negative perceptions among locals still exist, there are many positive activities by Indonesian migrant workers that should be more exposed to the public in Taiwan.

Another social-religious area that can be improved and became an anchor for the people to people relationship is through marriages. According to KDEI Taipei, there are about 29,600 mix-marriages between Indonesian and Taiwanese (Interview, 31 May 2018). ${ }^{2}$ This is very important since Taiwan has a problem with the low rate of birth in the last decades, which has brought implications to the country

\footnotetext{
2 During interview, KDEI office could not show the real number of Indonesian-Taiwanese mix married since the staff did not have enough time to provide complete data and this is the estimation of the actual number.
} 
(Chen, 2012; W.-I. Lin \& Yang, 2009; Y.-W. Lin et al., 2007). It means that the role of Indonesia is significant in order to assist the countries to resolve low birth rate problems. Moreover, this will create a new culture and opportunities, not only for Taiwan but also for Indonesia to strengthen people to people contact. Empirical data revealed that many of the mix-married families of Taiwanese and Indonesia run the business in Taiwan mainly through "Toko Indo." The culture and language obstacles could basically be tackled since both societies have good communication and understanding with each other. The high number of Indonesian migrant workers studying, whether in Indonesian Open University in Taiwan or the local Taiwan institutions, became an important factor to improve understanding between the two nations, especially under people-to-people contact.

Political Opportunities. The unofficial relationship between Indonesia and Taiwan vis-à-vis the People's Republic of China was the main obstacle in the political aspect. Nevertheless, there is still an opportunity to enhance political relations. In this context is the willingness of the two governments to be honest and patient to maintain relationships. This is because only by this strategy will both countries meet the best momentum in areas where the relationship will benefit each other. Taiwan's New Southbound Policy is important to improving political relations. To Taiwan, this is a good opportunity to gain political benefit and international recognition, especially from the Southeast Asian countries, including Indonesia, as a notable member of ASEAN with big investment opportunities. Under this scheme is an important alternative to resolving the infrastructure problems in Indonesia vis-àvis China, which implemented a load system and unfair negotiation. The influx of Chinese migrant workers in Indonesia is the real evidence of how investment from the Chinese people contradicts the Indonesian law on investment (Indonesian Law No. 25, 2007). Of course, the Taiwanese investment in Indonesia should be committed to particular laws that pursue pro-local labour and technology transfer. This policy could be realised under Taiwan's New Southbound Policy.

\section{Conclusion}

This research concludes that the dynamics of Indonesian migrant workers in Taiwan are influenced by two factors (1) the state dilemma and (2) people's realities, and affecting the international relations between Indonesia and Taiwan. Using the G-to-G partial relations approach, this research found that state dilemma existed due to political constrain between Indonesia and Taiwan vis-à-vis China. For Indonesia, the state dilemma refers to the conflicts between its One China Policy and the national (economic) interests. On the contrary, the people's realities are the life experiences of individual Indonesian workers in Taiwan, from "unemployed at home" to "cohered with Taiwanese." Therefore, economic cooperation was chosen as a strategic policy to realize the relationship. In fact, under this scenario, many Indonesian workers are employed in Taiwan, which is followed by intensive contact between the two societies, not only workers. At the same time, Taiwan also increased in economic investment, which spikes significantly from time to time. Meanwhile, in the context of people-topeople contact, the G-to-G partial relationship discovered an interesting situation. Under the so-called New People-Centred Southbound Policy, the presence of Indonesian migrant workers directly strengthens the relationship between Indonesia and Taiwan amid an unofficial diplomacy framework. Indeed, the people-to-people contact is perceived as the anchor of the relationship at the very lowest level and arguably meaningful. This because based on the fieldwork research, both societies were close together despite various dissimilarities. Thus, from the Indonesian 
migrant workers' perspective, the Indonesian and Taiwan governments should consider some challenges and opportunities to resolve the problems. In the end, it is expected that political communication between the two countries could be conducted smoothly, equally, with mutual trust, and respect for each other.

\section{References}

AN Bakar. (2009). Malaysian New ITC Policy: Regulatory Reform and the New Mode of Governance. Journal of Administrative Science, 6(1), 133-160. Retrieved from https://jas.uitm.edu.my/images/2009_ JUNE/6.pdf

Anderson, C. (2010). Presenting and evaluating qualitative research. American journal of pharmaceutical education, 74(8), 141-141. https://doi.org/10.5688/aj7408141

Ataman, M. (2003). The Impact of Non-State Actors on World Politics: A Challenge to Nation-States. Alternatives: Turkish Journal of International Relations, 2(1), 4266. Retrieved from https://dergipark.org. tr/en/download/article-file/19401

Atje, R., \& Gaduh, A. B. (1999). IndonesiaChina Economic Relations: An Indonesian Perspective. Jakarta: CSIS.

Barston, R. (2019). Modern Diplomacy. London: Routledge.

BNP2TKI. (2019). Data Penempatan dan Perlindungan TKI Periode 1 Januari - 31 Maret 2019. Retrieved from Jakarta: http://portal.bnp2tki.go.id/read/14229/ Data-Penempatan-dan-PerlindunganTKI-Periode-1-JANUARI-S.D-31MARET-2019.html

Cathcart, A., \& Denney, S. (2013). North Korea's Cultural Diplomacy in the Early Kim Jong-un Era. North Korean Review, 9(2), 29-42. Retrieved from www.jstor.org/ stable/43908918

Chen, Y.-H. (2012). Trends in Low Fertility and Policy Responses in Taiwan. The Japanese Journal of Population 10(1), 78-88. Retrieved from http://www.ipss.go.jp/webj-ad/ webjournal.files/population/2012_Vol.10/ Web\%20Journal_Vol.10_04.pdf

Cho, Y. Y. (2012). Public Diplomacy and South Korea's Strategies. The Korean Journal of International Studies, 10(2), 275-296. Retrieved from http://www.kaisnet.or.kr/ resource/down/10_2_05.pdf

Chou, B. (2019). Asus, with Dominant Market Share in Indonesia, Now Moves on to Capture Mindshare. Meet Startup@TW 13 August 2019. Retrieved from https://meet. bnext.com.tw/intl/articles/view/45267

Chou, J., \& Kuo, C.-h. (2016). Indonesian workers treated well in Taiwan: official. Focus Taiwan 14 January 2016. Retrieved from http://focustaiwan.tw/news/ asoc/201601140004.aspx

Cull, N. (2010). Public diplomacy: Seven lessons for its future from its past. Place Branding and Public Diplomacy, 6, 11-17. https://doi. org/10.1057/pb.2010.4

Etikan, I., Musa, S. A., \& Alkassim, R. S. (2016). Comparison of Convenience Sampling and Purposive Sampling. American Journal of Theoretical and Applied Statistics, 5(1), 1-4. https://doi.org/10.11648/j. ajtas.20160501.11

Faustina, A. (2015). Corrdinating Migrant Labor Policy between Taipei and Jakarta: The case of runaway Indonesian workers. (M.A. Thesis), National Chengchi University, Taipei.

Gilboa, E. (2006). Public Diplomacy: The Missing Component in Israel's Foreign Policy. Israel Affairs, 12(4), 715-747. https:// doi.org/10.1080/135333310600890067

Indonesian Law No. 25. (2007). Undang-Undang No. 25/2007 on Investment.

Kabinawa, L. N. R. W. (2013). Economic and Socio-Cultural Relations between Indonesia and Taiwan: An Indonesian Perspective, 1990-2012. Journal of ASEAN Studies, 1(2), 140-163.

KDEI Taipei. (2014). Sejarah KDEI Taipei Retrieved from http://www.kdei-taipei. 
org/index.php/2014-08-11-03-58-09/ sejarah-singkat. http://www.kdei-taipei. org/index.php/2014-08-11-03-58-09/ sejarah-singkat

Keliat, M. (2003). ASEAN dan Dialog 'Peopleto-People. CIVIC, 1(2), 1-10. Retrieved from http://staff.ui.ac.id/system/files/ users/make09/material/1-makmur.pdf

Koike, M. (2015). Indonesian Migrant Workers and their "Ethnic Communities" in Taiwan. St. Andrew's University Sociological Review 49(1), 27-48. Retrieved from https://ci.nii.ac.jp/naid/110009957896/

Lin, W.-I., \& Yang, S.-Y. (2009). From Successful Family Planning to the Lowest of Low Fertility Levels: Taiwan's Dilemma. Asian Social Work and Policy Review 3, 95-112. Retrieved from https://onlinelibrary. wiley.com/doi/pdf/10.1111/j.17531411.2009.00027.x

Lin, Y.-W., Yen, C.-Y., Yen, C.-L., Hou, Hsin-Yen, , \& Chu, Y.-C. (2007). The Causes and Effects of the Declining Birth Rate in Taiwan. Retrieved from Tainan City: http://ir.lib.ksu.edu.tw/bi tstream/987654321/704/1/\%E5\%B0\%88\%E9 \%A1\%8C\%E8\%A3\%BD\%E4\%BD\%9C.pdf

Loveband, A. (2003). Positioning the Product: Indonesian Migrant Women Workers in Contemporary Taiwan. Retrieved from Hong Kong:

Mashitah, S. D. (2017). A bilateral relation between Indonesia and Taiwan: A case study of higher educaational cooperation between Aceh and Taiwan (2010-2015). (M.A. Thesis), National Chengchi University, Taipei.

Medzini, M. (2012). Reflections on Israel's Public Diplomacy. Bulletin du Centre de recherche français à Jérusalem [En ligne], 23. Retrieved from http://journals. openedition.org/bcrfj/6829

Melchert, P. (2017). Indonesian Migrants in Taiwan: Religion and Life-styles. Retrieved from Münster:

Mo, J., \& Hahn, K. S. (2005). Public Diplomacy and North Korea Policy: Diverging Effects of U.S. Messages in the United States and South Korea. Journal of East Asian Studies, 5(2), 191-214. Retrieved from www.jstor. org/stable/23418288

Mohajan, H. K. (2018). Qualitative Research Methodology in Social Sciences and Related Subjects. Journal of Economic Development, Environmentand People, 7(1),23-48. Retrieved from https://mpra.ub.uni-muenchen. de/85654/1/MPRA_paper_85654.pdf

Mursitama, T. N. (2012). Second Track Diplomacy in ASEAN+3: The Case of Indonesia and Network of East Asian Think-Tanks (NEAT). International Affairs and Global Strategy, 5, 5-10. Retrieved from https://ssrn.com/abstract=2184311

Norrakiah A. S., \& Dahlan, H. A. (2015). Current Trend for Food Safety and Halal Measures. Paper presented at the ASEAN Community Conference 11-12 November, Bangi, Malaysia.

Payne, J. Gregory,. (2009). Reflections on Public Diplomacy: People-to-People Communication. American Behavioral Scientist, 53(4), 579-606. https://doi. org/10.1177\%2F0002764209347632

Prihatin, S. D. (2007). Potret Buram Perlindungan Tenaga Kerja Indonesia. Jurnal Ilmu Sosial dan Ilmu Politik, 10(3), 325-342. https://doi. org/10.22146/jsp.11010

Rawnsley, G. D. (2014). Taiwan's Soft Power and Public Diplomacy. Journal of Current Chinese Affairs, 43(3), 161-174. Retrieved from https://journals.sagepub.com/doi/ pdf/10.1177/186810261404300307

Rickards, \& Jane. (2017). Taiwan Looks Southward. Taiwan Business Topics. Retrieved from https://topics.amcham. com.tw/2017/05/taiwan-looks-southward/

Ruenwai, N. (2006). Science and technology information in Thailand: policies, strategies and provision. (PhD Thesis), Loughborough University, Loughborough, UK.

Saner, R., \& Yiu, L. (2001). International Economic Diplomacy: Mutation in the post-modern 
times. Den Haag: Netherland Institute of International Relations "Clingendael".

Schiff, A. (2010). “Quasi Track-One” Diplomacy: An Analysis of the Geneva Process in the Israeli-Palestinian Conflict1. International Studies Perspectives, 11(2), 93-111. https:// doi.org/10.1111/j.1528-3585.2010.00396.x

Setyaningsih, R. P. (2011). Job satisfaction of Indonesian workers in Taiwan. (M.A. Thesis), National Chengchi University, Taipei.

Sukma, R. (1994). Recent Developments in Sino-Indonesian Relations. Contemporary Southeast Asia, 16(1), 35-45. Sukma, R. (1995). The Evolution of Indonesia's Foreign Policy: An Indonesian View. Asian Survey, 35(3), 304-315.

Sundaryani, F. S., \& Wirayani, P. (2016). Taiwan promises increased investment in Indonesia. The Jakarta Post, December 1. Retrieved from https://www. thejakartapost.com/news/2016/12/01/ taiwan-promises-increased-investmentin-indonesia.html

Tam, L. (2019). Interpersonal approaches to relationship building: Diplomat as a human agent of public diplomacy. Place Branding and Public Diplomacy, 15(2), 134142. Retrieved from https://eprints.qut. edu.au/119171/

TETO Jakarta. (2017). Taiwan-Indonesia Relations Retrieved from http://www.roctaiwan.org/id_en/post/1199.html http:// www.roc-taiwan.org/id_en/post/1199. html

Tsay, C.-1. (2015). Migration between Southeast Asia and Taiwan: Trends, Characteristics and Implications. Journal of ASEAN Studies, 3(2), 68-92. https://doi.org/10.21512/jas. v3i2.842

Waltz, K. N. (1979). Theory of International Politics. Reading, Mass.: Addison-Wesley. Yuniarto, R. (2014). Making Connection": Indonesian Migrant Entrepreneurial Strategies in Taiwan". Journal of Identity and Migration Studies 8(1), 95-119. Yuniarto, R. (2015). Social Activist, Patron, and Broker: Indonesian Migrant Entrepreneurs in Taiwan. Ritsumeikan Journal of Asia Pacific Studies, 34, 106-120.

Zhou, T. (2014). China and the Thirtieth of September Movement. Indonesia, 98(29-58). 